\title{
Production and immobilization of partially purified lipase from Penicillium chrysogenum
}

\author{
Shafei, M. S.* and Allam, R. F. \\ Chemistry of Natural and Microbial Products Dept. \\ NRC, Dokki, Cairo, Egypt. \\ E-mail:mona sayed@hotmail.com
}

Received 6 April 2009; received in revised form 28 February 2010; accepted 2 March 2010

\begin{abstract}
An extracellular lipase from Penicillium chrysogenum produced maximal activity $225 \mathrm{U} / \mathrm{mL}$ after four days at $\mathrm{pH} 6.5$. It was partially purified 4.1 fold by ammonium sulphate precipitation (70\%). The enzyme was immobilized on various carriers viz. alginate, k-carrageenan and polyacrylamide gel. The immobilization yield of enzyme immobilized in kcarrageenan and polyacrylamide gel $(63.41 \%$ and $48.93 \%$ respectively) was low in comparison to that immobilized with alginate $(81.57 \%)$. Different concentrations of alginate were tried to study their effect on lipase production. Maximum immobilization yield was observed with $3 \%$ alginate. The optimal $\mathrm{pH}$ of the partially purified lipase was 7.5 and the optimum temperature was $35^{\circ} \mathrm{C}$. At $60^{\circ} \mathrm{C}$ the immobilized enzyme retained $62.79 \%$ of its activity. Broader pH tolerance and higher heat stability could be achieved by this method. Immobilized lipase retained $72.09 \%$ relative activity after six hydrolysis cycles.
\end{abstract}

Keywords: lipase, Penicillium chrysogenum, immobilization, alginate, k-carrageenan, polyacrylamide

\section{INTRODUCTION}

In their natural environment, lipases (EC 3.1.1.3) catalyze the hydrolysis of esters formed from glycerol and longchain fatty acids (Sharma et al., 2001; Rodrigues et al., 2008). However, under appropriate experimental conditions, these enzymes are also very active biocatalysts for the esterification of fatty acids, alcoholysis and transesterification reactions (Balcão et al., 1996; Pandey et al., 1999). Many lipases from microbial sources have been investigated and found to be promising catalysts for the hydrolysis and synthesis of fats and oils. Some of the commercially important lipase producing fungi are: Rhizopus arrhizus, Rhizopus japanicus, Mucor miehei, Aspergillus niger, Rhizopus niveus, Candida rugosa (Benjamin and Pandey, 1998; Ellaiah et al., 2004), Mucor sp. (Abbas et al., 2002), Aspergillus terreus (Gulati et al., 1999), Penicillium sp. (Pimentel et al., 1997; Lima et al., 2003).

Versatility of lipase leads to multiple industrial applications in food and flavor making, pharmaceuticals, synthesis of carbohydrate esters, amines and amides biodetergents and recently cosmetics and perfumery. In order to use them more economically and efficiently in aqueous as well as in non-aqueous solvents, their activity, selectively and operational stability can be modified by immobilization (Hung et al., 2003).

Immobilization of enzymes is the key to expand the applications of these natural catalysts by enabling easy separation and purification of products from reaction mixtures and efficient recovery of enzyme proteins. The most explored approach to immobilize enzymes has involved the use of solid supports via a variety of mechanisms such as adsorption on hydrophobic supports (Palomo et al., 2007; Blanco et al., 2007) or entrapment encapsulation (Kawakami and Yoshida, 1996; Wang and Hsieh, 2008) or covalent attachment to solid supports (Knezevic et al., 2006; Lozano et al., 2007; Foresti and Ferreira, 2007).

With immobilized enzymes, improved stability, reuse, continuous-operation, possibility of better control of reaction, high purity and product yields and hence more favourable economic factors can be expected (Ruckenstein and Wang, 1993).

Entrapment, one of the immobilization techniques, can be defined as physical restriction of enzyme within a confined space or network. Gelation of polyanionic or polycationic polymers by the addition of multivalent counter-ions is a simple and common method of enzyme entrapment. Alginates are one of the most frequently used polymers due to their mild gelling properties and nontoxicity. Alginate is an anionic linear copolymer composed of 1,4 -linked $\beta$-D-mannuronic acid and $\alpha$-L-gluronic acid in different proportions and sequential arrangements (Won et al., 2005).

Most lipases used in biotechnological applications are produced by fungi and bacteria. Filamentous fungi are interesting sources of lipases because they produce extracellular lipases. In this regards, the lipase of Penicillium sp. is among the well-known lipase producers mainly used in the dairy industry (Pimentel et al., 1994; 1997). 
The present paper deals with the production, partial purification and the immobilization of $P$. chrysogenum lipase using different entrapment techniques with matrices calcium alginate, $k$-carrageenan and polyacrylamide gel.

\section{MATERIALS AND METHODS}

\section{Microorganism}

$P$. chrysogenum used in the present work was kindly obtained from Natural and Microbial Products Chemistry Dept., National Research Centre, Cairo, Egypt.

\section{Media and growth conditions}

\section{Culture media}

$P$. chrysogenum was cultured in the following media $(\mathrm{g} / \mathrm{L}$ in distilled water): yeast extract 5 , olive oil $10, \mathrm{KNO}_{3} 2$, $\begin{array}{lllll}\mathrm{MgSO}_{4} \cdot 7 \mathrm{H}_{2} \mathrm{O} & 0.5, & \mathrm{~K}_{2} \mathrm{HPO}_{4} \quad 1, \quad \mathrm{ZnSO}_{4} \cdot 7 \mathrm{H}_{2} \mathrm{O} & 0.44\end{array}$ $\mathrm{FeSO}_{4} \cdot 7 \mathrm{H}_{2} \mathrm{O} 1.1, \mathrm{MnSO}_{4} \cdot 7 \mathrm{H}_{2} \mathrm{O} 0.2$; and $\left(\mathrm{NH}_{4}\right)_{2} \mathrm{SO}_{4} 10$ at $\mathrm{pH} 7.0$ using phosphate buffer.

\section{Cultivation}

Cultures were carried out in Erlenmeyer flasks $(250 \mathrm{~mL})$ with $50 \mathrm{~mL}$ of medium. The inoculum was prepared in 100 $\mathrm{mL}$ Erlenmeyer flasks with $20 \mathrm{~mL}$ of medium. The cultures were inoculated with $1 \mathrm{~mL}$ of spores suspension $\left(10^{8} \mathrm{~m} / \mathrm{L}\right)$ and the flasks were agitated at $120 \mathrm{rpm}$ at $30^{\circ} \mathrm{C}$. After 48 $\mathrm{h}$, the whole volume was transferred into $250 \mathrm{~mL}$ Erlenmeyer flasks with $50 \mathrm{~mL}$ of liquid using the same conditions of temperature and agitation. At time intervals, samples were withdrawn from the growth medium and then filtered to get the sample without cells (Lima et al., 2003).

\section{Protein estimation}

The protein content of the enzyme preparations was determined according to the method described by Lowry and coworkers (1951).

\section{Biomass estimation}

The mycelial biomass obtained after growth, was separated by filtration, washed by distilled water and dried. It was dried in an oven $60^{\circ} \mathrm{C}$ and reweighed till constant weight.

\section{Partial purification by $P$. chrysogenum lipase}

The culture broth harvested at the end of cultivation period mycelia was centrifuged at $10,000 \times g$ for $10 \mathrm{~min}$ at $4{ }^{\circ} \mathrm{C}$. The supernatant obtained was fractionated with $70 \%$ ammonium sulphate and kept standing overnight at $4{ }^{\circ} \mathrm{C}$. The precipitate was collected by centrifuginge at $10,000 \times$ $g$ for $5 \mathrm{~min}$ at $4{ }^{\circ} \mathrm{C}$, dialysed against distilled water. The dialyzed enzymatic fraction was subjected to protein and enzyme immobilization studies (Kanwar and Goswami 2002).

\section{Immobilization of partially purified lipase}

\section{Calcium alginate beads}

Two milliliter of lipase solution was mixed with $20 \mathrm{~mL}$ of sodium $(1,2,3$ and $4 \% \mathrm{w} / \mathrm{v})$ and then the mixture was stirred thoroughly to ensure complete mixing. As soon as the mixed solution was dripped into $40 \mathrm{~mL}$ of $\mathrm{CaCl}_{2}$ solution with a syringe, Ca-alginate beads were formed. After $20 \mathrm{~min}$ of hardening the beads were collected by filtration, then washed with tris- $\mathrm{HCl}$ buffer $(0.2 \mathrm{M} \mathrm{pH} 7.5)$ several time to remove the unbound enzyme (Won et al., 2005).

\section{k-Carrageenan entrapment method}

Eighteen milliliter of $\mathrm{k}$-carrageenan $(4 \% \mathrm{w} / \mathrm{v})$ maintained at $40-50{ }^{\circ} \mathrm{C}$ was mixed with $2 \mathrm{~mL}$ of lipase solution, poured into sterile 4 inch diameter Petri plates and allowed to solidify. It was then cut into equal small blocks. The kcarrageenan was cured in $2 \% \mathrm{KCl}$ for $1 \mathrm{~h}$ in the refrigerator. These blocks were washed thoroughly two or three times with sterile distilled water (Ellaiah et al., 2004).

\section{Polyacrylamide gel entrapment method}

Two milliliter of lipase solution was added to $10 \mathrm{~mL}$ chilled sterile water. To $10 \mathrm{~mL}$ sterile potassium phosphate buffer $(\mathrm{pH} 7.0,0.2 \mathrm{M})$ the following chemicals were added: acrylamide $2.85 \mathrm{~g}$, bisacrylamide, $0.15 \mathrm{~g}$; ammonium persulphate, $10 \mathrm{mg}$ and $1 \mathrm{~mL} N, \mathrm{~N}, \mathrm{~N}^{1}, \mathrm{~N}^{1}$-tetramethyl ethylenediamine (TEMED). The chilled lipase solution and chilled potassium phosphate buffer were mixed well and poured into sterile flat bottom 4 inch diameter Petri plates. After polymerization the acrylamide gel was cut into equal size cubes. The acrylamide cubes were cured in sodium phosphate buffer ( $\mathrm{pH} 7.0,0.2 \mathrm{M})$ for $1 \mathrm{~h}$ in the refrigerator. These cubes were washed thoroughly two to three times with sterile water (Ellaiah et al., 2004).

\section{Determination of $\mathrm{pH}$ and temperature effects on the lipolytic activity}

The optimal $\mathrm{pH}$ for free and immobilized enzyme activity was determined by incubating the enzyme-substrate at various $\mathrm{pH}$ from 5-6.5 using $0.1 \mathrm{~m}$ phosphate buffer and from 7-8.5 using $0.1 \mathrm{~m}$ Tris- $\mathrm{HCl}$ buffer. The effect of $\mathrm{pH}$ stability on lipase activity was measured with the enzyme (free and immobilized) previously incubated during $1 \mathrm{~h}$ at the desired $\mathrm{pH}$ and the residual activity was assayed at $\mathrm{pH}$ 7.5. The optimal temperature for both free and immobilized enzymes was determined by incubating the reaction mixture at $25,30,37,40,45,50^{\circ} \mathrm{C}$. Controls were performed with boiled enzyme. For thermal stability study, the enzyme (free and immobilized) was incubated at various temperatures for $1 \mathrm{~h}$ and the residual activity was measured. 


\section{Assay for lipase activity}

A suitable volume $(1 \mathrm{~mL})$ of the culture filtrate was mixed with $2.5 \mathrm{~mL}$ of deionized water and $1 \mathrm{~mL}$ of to $0.1 \mathrm{M}$ Tris$\mathrm{HCl}$ buffer $(\mathrm{pH} 7.5) .3 \mathrm{~mL}$ of $10 \%(\mathrm{v} / \mathrm{v})$ triglyceride emulsion prepared in $10 \% \quad(\mathrm{w} / \mathrm{v})$ gum arabic by homogenizing in top drive homogenizer for 10 min were then added.

The mixture was incubated for $2 \mathrm{~h}$ at $35^{\circ} \mathrm{C}$ in shaking water bath after which $10 \mathrm{~mL}$ of $99 \%$ acetone (absolute) was added. The resulting mixture was then titrated against $0.05 \mathrm{~N} \mathrm{NaOH}$ using thymolphthalein indicators. It should be noted that $\mathrm{NaOH}$ was previously standardized against standard $0.05 \mathrm{~N} \mathrm{HCl}$ using phenolphthaleine indicators. Blanks obtained on using boiled enzyme samples and the activities were obtained in terms of $\mathrm{U} / \mathrm{mL}$ of enzyme solution. The lipase unit was defined as that produces 1 $\mu \mathrm{mol}$ of free fatty acids under assayed conditions (Parry et al., 1966).

\section{Repeated use of lipase immobilized in the alginate beads}

In order to test the stability of lipase entrapped in the caalginate beads, the beads were used several times for the hydrolysis reaction. Each run lasted for $2 \mathrm{~h}$ after which the beads were separated and washed with $0.1 \mathrm{M}$ Tris- $\mathrm{HCl}$ $(\mathrm{pH}$ 7.5). The reaction medium was the replaced with fresh medium. The activity of freshly prepared beads in the first run was defined as $100 \%$.

\section{RESULTS AND DISCUSSION}

\section{Production of extracellular lipase from chrysogenum and the effect of $\mathrm{pH}$}

$P$. chrysogenum produced an extracellular lipase during growth on a medium containing olive oil as the sole carbon source.

The results recorded in Figure 1 indicated that the production of lipase increased steadily with the cultivation time and the best enzyme production, about $205 \mathrm{U} / \mathrm{mL}$ was reached at $4.50 \mathrm{~g} / 100 \mathrm{~mL}$ dry weight after 4 days of cultivation. Maximum lipase production was observed during the iodophase of growth and then the activity declined. In our study, the secretion of lipase was induced by olive oil, as no other organic nutrient or carbon substrate other than olive oil was supplemented in the growth medium for the production of lipase. Lipase production is generally induced by the lipid substrates. The favorable effect of olive oil and oleic acid on lipase production has been observed by various researchers (Chahinian et al., 2000; Fadiloglu and Erkmen, 2002; Lima et al., 2003). However, the enzyme production decreased on increasing the incubation period showing lipase activity of $155 \mathrm{U} / \mathrm{mL}$ after 7 days of incubation. This may be attributed to the fact that lipase production has been frequently inhibited by the end products namely, glycerol and fatty acids (del Rio et al., 1990; Kanwar and Goswami, 2002).

With regard to the effect of different buffer values of the fermentation medium on lipase production (Table 1), phosphate buffer was used to adjust the fermentation medium for lipase production.

$P$. chrysogenum was able to grow and secrete lipase over a wide range of $\mathrm{pH}$ values, ranging from 4.0 to 9.0 . Growth was maximal between $\mathrm{pH}$ 6.0-7.0 and lipase production was maximal between $\mathrm{pH} 6.5-7.0$. A relatively small amount of the enzyme was detected at pH 9.0 (120 $\mathrm{U} / \mathrm{mL}$ ). The $\mathrm{pH}$ optima for extracellular lipase activity for a variety of Penicillium sp. have been investigated. The results agreed with those of Lebyreva and Marchenkova (1983) who adjusted the $\mathrm{pH}$ of the fermentation media at 7.0 for lipase production using Penicillium roquefortii BKMF-2019. Similar results were obtained by Sztajer and Maliszewka (1989) and Pimentel et al. (1994) who found that the best $\mathrm{pH}$ for lipase production was 7.2 and 7.5 respectively using Penicillium citrinum.

\section{Partial purification of $\boldsymbol{P}$. chrysogenum lipase}

A summary of $P$. chrysogenum lipase partially purified is presented in Table 2. The lipase was partially purified about 4.10 fold over the crude extract with $60.44 \%$

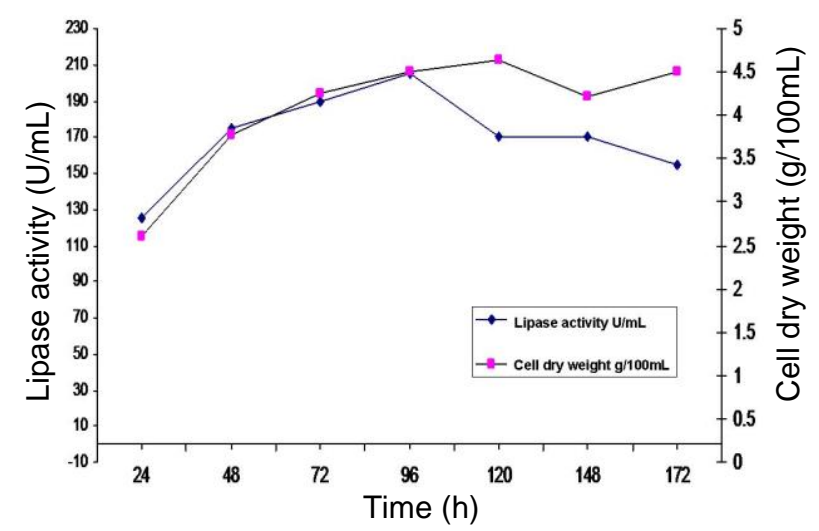

Figure 1: Effect of different incubation period on lipase activity by $P$. chrysogenum

Table 1: Effect of different buffered $\mathrm{pH}$ medium on lipase activity by $P$. chrysogenum

\begin{tabular}{ccc}
\hline $\mathrm{pH}$ & Lipase activity $(\mathrm{U} / \mathrm{mL})$ & $\begin{array}{c}\text { Cell dry weight } \\
(\mathrm{g} / 100 \mathrm{~mL})\end{array}$ \\
\hline 4.0 & 140 & 2.84 \\
4.5 & 165 & 3.01 \\
5.0 & 175 & 3.25 \\
5.5 & 190 & 3.82 \\
6.0 & 210 & 4.00 \\
6.5 & 225 & 4.20 \\
7.0 & 205 & 4.50 \\
7.5 & 160 & 4.41 \\
8.0 & 155 & 4.33 \\
9.0 & 120 & 4.30 \\
\hline
\end{tabular}


Mal. J. Microbiol. Vol 6(2) 2010, pp. 196-202

Table 2: A profile of partial purified $P$. chrysogenum lipase

\begin{tabular}{lcccccccc}
\hline $\begin{array}{l}\text { Purification } \\
\text { steps }\end{array}$ & $\begin{array}{c}\text { Collected } \\
\text { volume } \\
(\mathrm{mL})\end{array}$ & $\begin{array}{c}\text { Protein } \\
(\mathrm{mg} / \mathrm{mL})\end{array}$ & $\begin{array}{c}\text { Lipase } \\
\text { activity } \\
(\mathrm{U} / \mathrm{mL})\end{array}$ & $\begin{array}{c}\text { Total } \\
\text { protein } \\
(\mathrm{mg})\end{array}$ & $\begin{array}{c}\text { Total } \\
\text { activity } \\
\text { units }\end{array}$ & $\begin{array}{c}\text { S.E.A. } \\
(\mathrm{U} / \mathrm{mg})\end{array}$ & $\begin{array}{c}\text { Recovery } \\
(\%)\end{array}$ & $\begin{array}{c}\text { Purification } \\
\text { fold }\end{array}$ \\
\hline $\begin{array}{l}\text { Crude filtrate } \\
\text { ppt by 70\% }\end{array}$ & 100 & 25 & 225 & 2500 & 22500 & 9.0 & 100 & 1.0 \\
$\begin{array}{l}\text { ammonium } \\
\text { sulphate }\end{array}$ & 40 & 9.2 & 340 & 368 & 13600 & 36.95 & 60.44 & 4.10 \\
\hline
\end{tabular}

Table 3: Immobilization of $P$. chrysogenum lipase using different carriers

\begin{tabular}{lcccc}
\hline Carriers & $\begin{array}{c}\text { Enzyme added } \\
(\mathrm{U} / \mathrm{g} \text { carrier A) }\end{array}$ & $\begin{array}{c}\text { Unbound enzyme } \\
(\mathrm{U} / \mathrm{g} \text { carrier B) }\end{array}$ & $\begin{array}{c}\text { Bound Enzyme } \\
(\mathrm{U} / \mathrm{g} \text { carrier I) }\end{array}$ & $\begin{array}{c}\text { Immobilization yield } \\
\%\end{array}$ \\
\hline Ca-alginate & 280 & 90 & 155 & 81.57 \\
k-Carrageenan & 280 & 75 & 130 & 63.41 \\
Polyacryl amide & 280 & 45 & 115 & 48.93 \\
\hline
\end{tabular}

Immobilization yield $\%=\frac{\mathrm{I}}{\mathrm{A}-\mathrm{B}} \times 100$

Table 4: Effect of alginate concentration using immobilized $P$. chrysogenum lipase

\begin{tabular}{lcccc}
\hline $\begin{array}{l}\text { Alginate } \\
\text { concentration (\%) }\end{array}$ & $\begin{array}{c}\text { Enzyme added } \\
\text { (U/g carrier) }\end{array}$ & $\begin{array}{c}\text { Unbound enzyme } \\
\text { (U/g carrier) }\end{array}$ & $\begin{array}{c}\text { Bound enzyme } \\
\text { (U/g carrier) }\end{array}$ & $\begin{array}{c}\text { Immobilization yield } \\
\%\end{array}$ \\
\hline 1 & 280 & 100 & 120 & 66.66 \\
2 & 280 & 90 & 155 & 81.57 \\
3 & 280 & 75 & 175 & 85.36 \\
4 & 280 & 105 & 120 & 62.85 \\
\hline
\end{tabular}

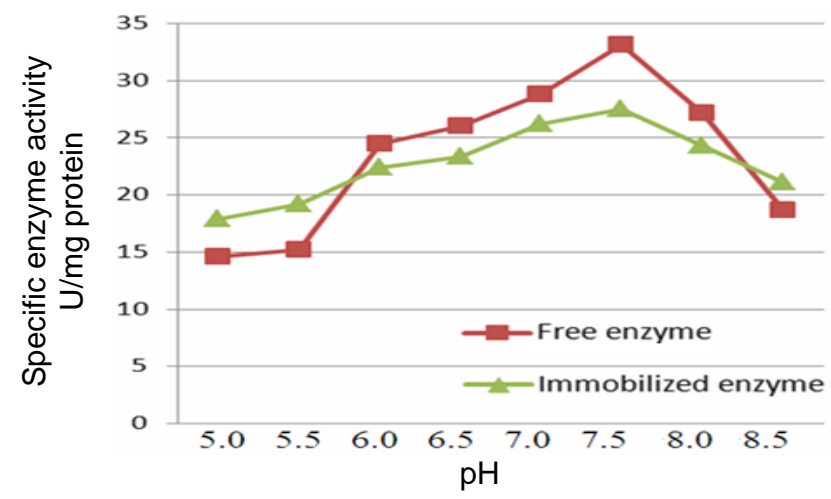

Figure 2: Effect of substrate $\mathrm{pH}$ on the specific enzyme activity of free and immobilized lipase

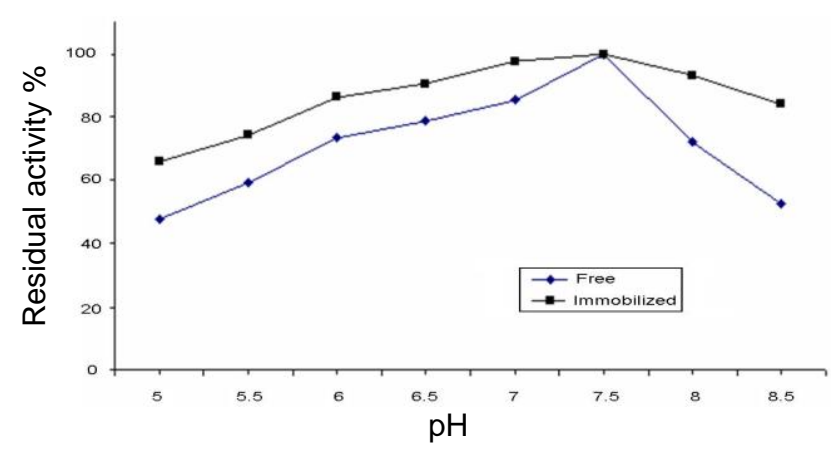

Figure 3: $\mathrm{pH}$ stability of the free and immobilized $P$. chrysogenum lipase recovery using $70 \%$ ammonium sulphate for precipitation. The specific enzyme activity of the partially purified lipase increased to $36.95 \mathrm{U} / \mathrm{mg}$ proteins. Similar results were obtained by Shu et al. (2006) and Saxena et al. (2003) who used $70 \%$ ammonium sulphate in the partial purification of lipase.

\section{Immobilization of $P$. chrysogenum lipase using different carriers}

The experimental results of immobilized $P$. chrysogenum lipase using different various entrapment techniques are shown in Table 3 . The immobilization yield of lipase entrapped in calcium alginate $(81.57 \%)$ was higher than that of enzyme entrapped in k-carrageenan (63.41\%) and polyacrylamide (48.93\%). The low yield with kcarrageenan and polyacrylamide blocks may be due to the diffusional resistance of nutrients and oxygen into the matrices. These results are in accordance with studies on A. niger (Jamil and Omar, 1992; Ellaiah et al., 2004) and Candida rugosa (Ferrer and Carles, 1992). On the contrary, Hemachander and coworkers (2001) found that polyacrylamide gave the best performance using Ralstonia pickettii.

Therefore, alginate was considered to be the best matrix for the production of lipase and the partially purified enzyme entrapped by sodium alginate was used for further investigation. 


\section{Effects of alginate concentration}

Due to the cross-linking between alginate and $\mathrm{Ca}^{2+}$ leads to gelation, alginate concentration is a major parameter for enzyme gel entrapment. Therefore effect of alginate concentration on immobilization yield was investigated. Alginate concentration was increased from 1 to $4 \%(\mathrm{w} / \mathrm{v})$ maintaining the $\mathrm{CaCl}_{2}$ concentration $(2 \% \mathrm{w} / \mathrm{v})$ As a result, the immobilization yield increased as shown in (Table 4) until it reached $85.36 \%$ at $3 \%$ alginate concentration. Immobilization yield decreased (62.85\%) on increasing alginate concentration $(4 \% \mathrm{w} / \mathrm{v})$. This is due to the conformational changes in the entrapped enzyme and/or limitation of substrate transfer from the bulk phase into the alginate beads as alginate concentration increased (Knezevic et al., 2002).

\section{Effect of pH on activity and stability of the free and immobilized $P$. chrysogenum lipase}

Effect of pH on the specific enzyme activity of both free and immobilized lipase of $P$. chrysogenum was studied by varying the $\mathrm{pH}$ of the reaction medium from $5.0-8.5$ and the $\mathrm{pH}$ profile is shown in Figure 2.

The lipase was found to be nearly alkaline lipase which showed higher specific enzyme activities for both free and immobilized enzyme at $\mathrm{pH} 7.5$ and it retained nearly $76.74 \%$ (compared to $\mathrm{pH} 7.5$ ) of the activity at $\mathrm{pH}$ 8.5 for immobilized lipase while $56.22 \%$ for free one. The variation of the residual activity of free and immobilized lipase with $\mathrm{pH}$ is shown in Figure 3 . The immobilized lipase was stable in the $\mathrm{pH}$ range from 6.5 to 8.0. Free lipase was stable in the $\mathrm{pH}$ range from 6.5 to 7.5 . This indicated that immobilization appreciably improved the stability of lipase in the neutral and alkaline region. Similar results were obtained on using immobilized Candida rugosa lipase on chitosan (Hung et al., 2003).

\section{Effect of temperature on activity and stability of the free and immobilized $P$. chrysogenum lipase}

The temperature dependence of the hydrolytic activity of free and immobilized lipase is shown in Figure 4. The optimum reaction temperature $\left(35^{\circ} \mathrm{C}\right)$ of the lipase was not altered by immobilization. The immobilized lipase demonstrated higher specific enzyme activities above $35{ }^{\circ} \mathrm{C}$ as compared to the free lipase. However denaturation of the enzyme occurred at $50{ }^{\circ} \mathrm{C}$ for immobilized lipase and at $45{ }^{\circ} \mathrm{C}$ for the free enzyme. These results indicate that lipase is more stable when immobilized in a matrix with higher hydrophobicity (Shaw et al., 1990).

Heat stability of the lipase entrapped in alginate matrices is much better than that of the corresponding free enzyme (Figure 5). Immobilized enzyme remained active up to $50{ }^{\circ} \mathrm{C}$ while the activity of the free enzyme started to decrease from $40{ }^{\circ} \mathrm{C}$. At $60{ }^{\circ} \mathrm{C}$ the residual activity of the immobilized lipase was $62.79 \%$ compared to $52.45 \%$ for free enzyme.
These results are in accordance with the concept that immobilized lipase provided a more rigid external

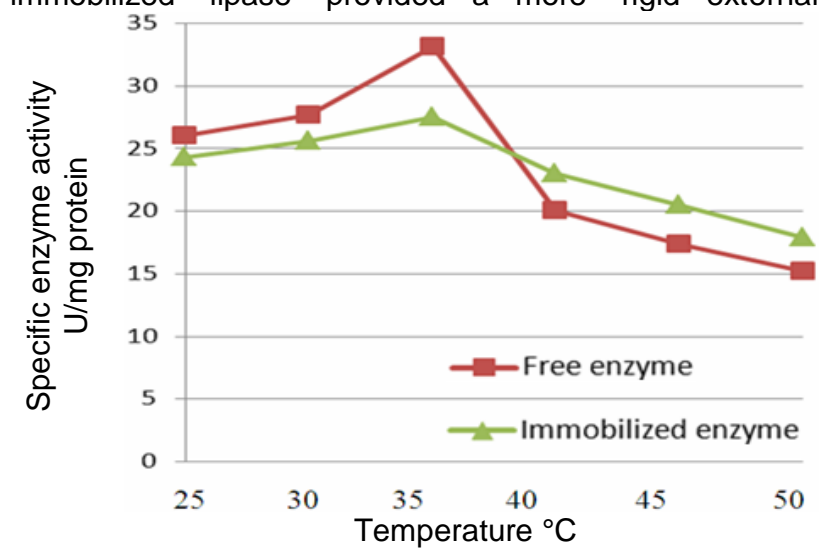

Figure 4: Effect of reaction temperature on the specific enzyme activity of free and immobilized $P$. chrysogenum lipase

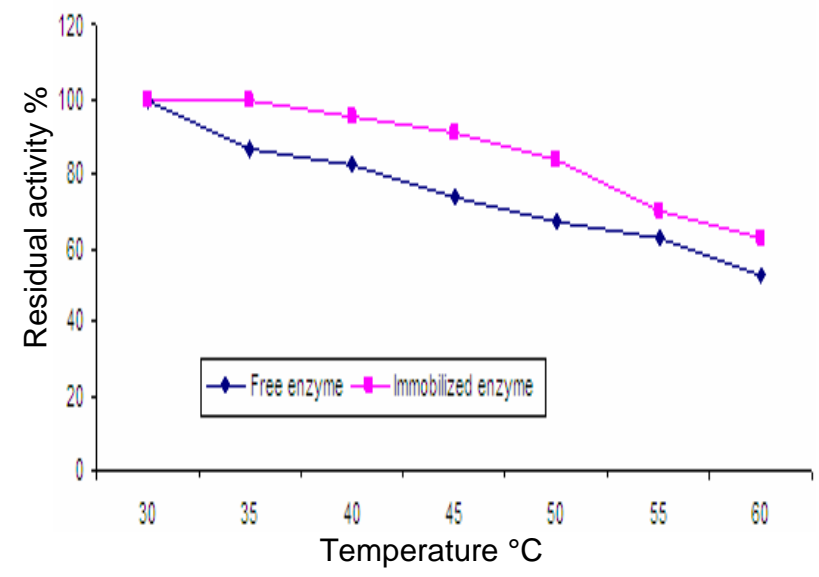

Figure 5: Thermal stability of free and immobilized lipase

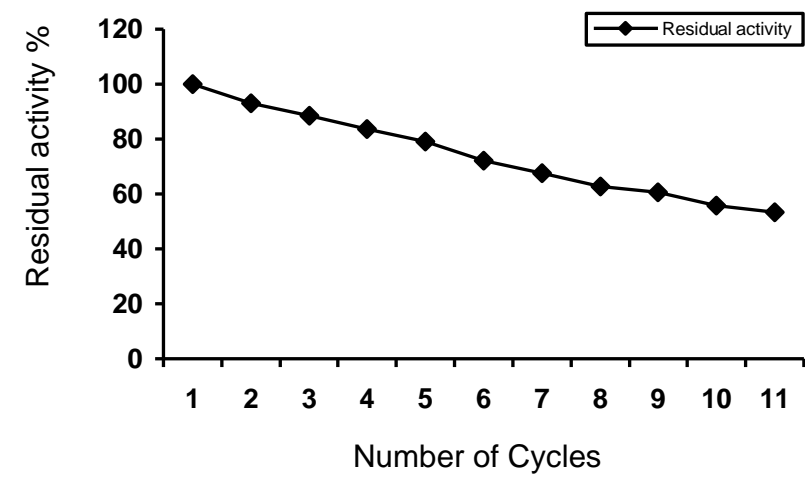

Figure 6: Effect of repeated use of immobilized $P$. chrysogenum lipase on residual activity at $\mathrm{pH}$ 7.5 and $35^{\circ} \mathrm{C}$

backbone for lipase molecules; the effect of higher temperature in breaking the interactions responsible for proper globular, catalytic active structure became less 
prominent, thus increasing the thermal stability of the immobilized enzyme (Dove and Madamwar, 2006).

\section{Reuse of the immobilized $P$. chrysogenum lipase}

One of the important characteristics of an immobilized enzyme is its stability and reusability over an extended period of time.

The repeated use of the immobilized $P$. chrysogenum lipase in hydrolysis of olive oil was studied. The residual activity of the immobilized enzyme at repeated use is shown in Figure 6. After 6 reuses, immobilized lipase retained $72.09 \%$ of its activity. Hung and coworkers (2003) found that the repeated use for immobilized $C$. rugosa lipase on chitosan retained $74 \%$ after 10 reuses. Similarly $\mathrm{Yi}$ and coworkers (2009) showed that the activity of immobilized lipase of $C$. rugosa on alanine chitosan beads relatined $77 \%$ of the initial activity after 10 times of reuse. On the contrary Won and coworkers (2005) found that the immobilized lipase of $C$. rugosa entrapped in Ca-alginate gel beads retained $72 \%$ after three uses.

\section{CONCLUSIONS}

The main objective of the present study was to increase the capacity of the local isolate $P$. chrysogenum to produce lipase through the application of the immobilization technique. $P$. chrysogenum lipase was partially purified about 4.1 fold with a specific activity of $36.95 \mathrm{u} / \mathrm{mg}$ protein. The immobilized enzyme was found to be stable over $\mathrm{PH}$ range 6.5-8. It was clarified to be tolerant within the temperature range of up to $60{ }^{\circ} \mathrm{C}$ with maximal activity at $35^{\circ} \mathrm{C}$. The enzyme can be reused up to 6 runs which is a promising technique for large-scale preparation of immobilized lipase for industrial applications.

\section{REFERENCES}

Abbas, H., Hiol, A., Deyris, V. and Comeau, L. (2002). Isolation and characterization of an extracellular lipase from Mucor sp. strain isolated from plam fruit. Enzyme and Microbial Technology 31, 968-975.

Balcão, V. M., Paiva, A. L. and Malcato, F. X. (1996). Bioreactors with immobilized lipases. Enzyme Microbial Technology 18, 392-416.

Benjamin, S. and Pandey, A. (1998). Candida rugosa and its lipases. Journal of Scientific and Industrial Research. 57, 1-9.

Blanco, R. M., Terreros, P., Munoz, N. and Serra, E. (2007). Ethanol improves immobilization on a hydrophobic support. Journal of Molecular Catalysis B: Enzymatic 47, 13-20.

Chahinian, H., Vanot, G., Ibrick, A., Rugani, N., Sarda, L. and Comeau, L. C. (2000). Production of extracellular lipases by Penicillium cyclopium, purification and characterization of a partial acylglycerol lipase. Bioscience, Biotechnology and Biochemistry 64, 215-222. del Rio, J. L., Serra, D., Valero, F., Poch, M. and Sola, C. (1990). Reaction scheme of lipase production by Candida rugosa growing on olive oil. Biotechnology Letters 12, 335-338.

Dove, R. and Madamwar, D. (2006). Esterification in organic solvents by lipase immobilized in polymer of PVA-alginate-boric acid. Process Biochemistry 41, 951-955.

Ellaiah, P., Prabhakar, T., Ramakrishna, B., Thaer Taleb, A. and Adinarayana, K. (2004). Production of lipase by immobilized cells of Aspergillus niger. Process Biochemistry 39, 525-528.

Fadiloglu, S. and Erkmen, O. (2002). Effects of carbon and nitrogen sources on lipase production by Candida rugosa. Turkish Journal of Engineering and Environmental Sciences 26, 249-254.

Ferrer, P. and Carles, S. (1992). Lipase production by immobilized Candida rugosa cells. Applied Microbiology and Biotechnology 37,737-741.

Foresti, M. L. and Ferreira, M. L. (2007). Analysis of the interaction of lipases with polypropylene of different structure and polypropylene modified glass surface. Colloids and Surfaces A: Physicochemical and Engineering Aspects 494, 147-155.

Gulati, R., Saxena, R. X., Cuptha, R., Yadav, R. P. and Davidson, W. S. (1999). Parameteric optimization of Aspergillus terreus lipase production and its potential inester synthesis. Process Biochemistry 35, 373-378.

Hemachander, C., Bose, N. and Puvanakrishnan, R. (2001). Whole cell immobilization of Ralstonia pickettii for lipase production. Process Biochemistry 36, 629633.

Hung, T. C., Giridhar, R., Chiou, S. H. and Wu, W. T. ( 2003). Binary immobilization of Candida rugosa lipase on chitosan. Journal of Molecular Catalysis B: Enzymatic 26, 69-78.

Jamil, N. I. and Omar, I. C. (1992). Lipase production using Asperigllus niger. Journal of Biosciences 3, 3141.

Kanwar, L. and Goswami, P. (2002). Isolation of Pseudomonas lipase produced in pure hydrocarbon substrate and its application in the synthesis of isoamyl acetate using membrane immobilized lipase. Enzyme and Microbial Technology 31, 727-735.

Kawakami, K. and Yoshida, S. (1996). Thermal stabilization of lipase by sol. gel entrapment in organically modified silicates formed on kieselguhr. Journal of Fermentation and Bioengineering 82, 239245.

Knezevic Z., Milosavic, N., Bezbradica, D., Jakovljevic, Z. and Pradanovic, R. (2006). Immobilization of lipase from Candia rugasa on Eupergitic supports by covalent attachment. Biochemical Engineering Journal 30, 269-278.

Knezevic, Z., Bobic, S., Milutinovic, A., Obradovic, B., Mojovic, L., Bugarski, B. (2002). Alginateimmobilized lipase by electrostatic extrusion for the purpose of palm oil hydrolysis in lecithin/isooctane system. Process Biochemistry 38, 313-318. 
Lebyreva, L. B. and Marchenkova, A. I. (1983). Lipolytic activity of the fungus Penicilium roqueforti. Applied Biochemistry and Microbiology 19, 67-70.

Lima, V. M. G., Krieger, N., Sarquiz, M. I. M., Mitchell, D. A., Ranos, L. P. and Fontana, J. D. (2003). Effect of nitrogen and carbon sources on lipase production by Penicillium, aurantiogriseum. Food Technology and Biotechnology 41, 105-110.

Lowry, O. H., Rosenbrough, N. J., Farr, A. L. and Randall, R. J. (1951). Protein measurement with the folin-phenol reagent. The Journal of Biological Chemistry 193, 265-275.

Lozano, P., DeDiego, T., Sauer, T. Vaultier, M. Gmouth, S. and Iborra, J. L. (2007). On the importance of the supporting material for the activity of immobilized Candida antarctica lipase B in ionic liquid hexane and ionic liquid/ supercritical carbon dioxide biphasic media. The Journal of Supercritical Fluids 40, 93-100.

Palomo, J. M., Segura, R. L., Fernandez-Lorente, G., Fernandez-Lafuente, R. and Guisan, J. M. (2007). Glutaraldehyde modification of lipases adsorbed on aminated supports. A simple way to improve their behaviour as enantioselective biocatalyst. Enzyme and Microbial Technology 40, 704-707.

Pandey, A., Benjamin, S., Soccol, C. R., Nigam, P., Krieger, N. and Soccol, V. T. (1999). The realm of microbial lipases in biotechnology. Biotechnology and Applied Biochemistry 29, 119-131.

Parry, R. M., Chandan, R. C. and Shahani, K. M. (1966) Rapid and sensitive assay for milk lipase. Journal of Dairy Science 49, 356-360.

Pimentel, M. C. B., Kreiger, N., Coelho, L. C. C. B. Fontana, J. D., Melo, E. H. M., Ledingham, W. M. and Lima Fillo, J. L. (1994). Lipase from a Brazilian strain of Penicillium citrinum. Applied Biochemistry and Biotechnology 49, 59-74.

Pimentel, M. C. B., Melo, E. H. M., Lima Filho, J. L., Ledingham, W. M. and Duran, N. (1997). Lipase from Brazilian strain Penicillium citrinum cultured in a simple inexpensive medium. Applied Biochemistry and Biotechnology 66, 185-195.

Rodrigues, D. S., Mendes, A., Adriano, W. S., and Gonçalves, L. R. B. (2008). Multipoint covalent immobilization of microbial lipase on chitosan and agarose activated by different methods. Journal of Molecular Catalysis B: Enzymatic 51, 100-109.

Ruckenstein, E. and Wang, X. (1993). Lipase immobilized on hydrophobic porous polymer supports prepared by concentrated emulsion polymerization and their activity in the hydrolysis of triacylglycerides. Biotechnology and Bioengineering 42, 821-828.

Saxena, R. K., Sheoran, A., Gir, B. and Davidson, W. S. (2003). Purification strategies from microbial lipases. Journal of Microbiological Methods 52, 1-18.

Sharma, R., Chisti, Y. and Banerjee, U. C. (2001) Production, purification, characterization and applications of lipases. Biotechnology Advance 19, 627-662.

Shaw, J. F., Chang, R. C., Wang, F. F. and Wang, Y. J. (1990). Lipolytic activities of a lipase immobilized on six selected supporting materials. Biotechnology and Bioengineering 35, 132-137.

Shu, C. H., Xu, C. J. and Lin, G. C. (2006). Purification and partial characterization of a lipase from Antrodia cinnamomea. Process Biochemistry 41, 734-738.

Sztajer, H. and Maliszewka, I. (1989). The effect of culture conditions on lipolytic productivity of Penicilium citrinun. Biotechnology Letters 11, 895898.

Wang, Y. and Hsieh, Y. L. (2008). Immobilization of lipase in polyvinyl alcohol (PVA) nanofibrous membranes. Journal of Membrane Science 309, 7381.

Won, K., Kim, S., Kim, K. J., Park, H. W. and Moon, S. J. (2005). Optimization of lipase entrapment in Caalginate gel beads. Process Biochemistry. 40, 21492154.

Yi, S. S., Noh, J. M. and Lee, Y. S. (2009). Amino acid modified chitosan beads: Improved polymer support for immobilization of lipase from Candida rugosa. Journal of Molecular Catalysis B: Enzymatic 57,123129. 